\title{
Does the Phaeocystis bloom affect the diel migration of the suprabenthos community?
}

\author{
Jean-Claude Dauvin ${ }^{a},{ }^{*}$, Nicolas Desroy $^{b}$, Lionel Denis ${ }^{a}$ and Thierry Ruellet ${ }^{a}$
}

\author{
a Station Marine de Wimereux, Université des Sciences et Technologie de Lille, FRE CNRS 2816 ELICO, 28 \\ Avenue Foch, BP 80, F-62930 Wimereux, France \\ ${ }^{\mathrm{b}}$ IFREMER, Département Laboratoire Environnement Littoral \& Ressources Aquacoles, 2, bis rue Grout de Saint- \\ Georges, BP 46, F-35042 Saint-Malo Cedex, France
}

*: Corresponding author : Dauvin J. C., email address : jean-claude.dauvin@univ-lille1.fr

\begin{abstract}
:
The suprabenthos comprises all bottom-dependent animals, mainly crustaceans (including decapods and peracarids), which perform - with varying amplitude, intensity and regularity - seasonal or daily vertical migrations above the sea floor. The presence of organisms in the Benthic Boundary Layer is determined by two general factors: (1) organism behaviour, which depends on the light penetration in the water column and (2) boundary-layer hydrodynamics. In the coastal zone of the eastern English Channel, during the spring Phaeocystis bloom, the presence of gelatinous colonies modifies the penetration of light in the water column, which may seriously affect the abundance and/or the behaviour of the suprabenthos community. To clarify this point, 19 suprabenthic hauls were taken with a modified Macer-GIROQ sledge both during the day and during the night, from March to June 2002 (i.e., before, during and after the bloom). Two sites, located in the coastal and offshore areas of the Ophelia medium sand macrobenthic community were investigated. The bloom had no effect on species richness and abundance in either site. However, the diel migrations of some dominant species - such as the cumaceans Pseudocuma longicornis and Pseudocuma similis, the mysid Gastrosaccus spinifer and the amphipod Stenothoe marina - were modified. During the bloom, diurnal and nocturnal suprabenthic abundances were similar, and in the absence of bloom, species remained benthic during the day. The permanent presence of suprabenthic species in the Benthic Boundary Layer could have a consequence on their predation by fish (mainly juveniles which preferentially consume small crustaceans in their diet), unless fish behaviour and predation efficiency - especially for visual predators - are also disturbed by changes in light intensity.
\end{abstract}

Keywords: Suprabenthos; English Channel; Phaeocystis bloom; Diel migration 


\section{Introduction}

As defined by Brunel et al. (1978), the suprabenthos comprises all bottom-dependent animals (mainly crustaceans, especially decapods and peracarids) that, with variable regularity, perform daily or seasonal vertical migrations. This biological compartment is particularly present in the Benthic Boundary Layer (BBL), which exhibits an accumulation and diversity of organisms swimming near the sea bottom in all marine environments (Mees and Jones, 1997). The presence of organisms in this layer is determined by two general factors: (1) organism behaviour, including swimming activities in response to changes in the light penetration in coastal area water columns, and (2) boundary-layer hydrodynamics (Mees and Jones, 1997; Dauvin and Vallet, 2006). The diel vertical migration is perhaps the most broadly distributed trait occurring in the diverse animal phyla living in aquatic environments. This phenomenon is sufficient in magnitude to affect whole populations and indeed whole ecosystems (Ohman et al., 1983; Ohman, 1990; Checkley et al., 1992; Hays, 2003). However such migrations involve major selective advantages for the participants: i) a capacity to avoid diurnal visual predators (Macquart-Moulin et al., 1987; Checkley et al., 1992), ii) the ability to decrease metabolic consumption in deeper colder waters during the day (Longhurst, 1976), iii) the use of other habitats during the pelagic phase, which may provide additional food resources (Fosså and Brattegard, 1990) and/or iv) aids for species dispersal, increasing the possibility of meeting a sexual partner (Hesthagen, 1973). But the nature of such advantages is controversial, and part of the confusion stems from the variable characteristics of such behaviour (Ohman, 1990). The diel vertical migration may vary depending on the stage of development of a species; it may also vary in time or place within a single species and between coexisting species (Ohman, 1990; Dauvin \& Zouhiri, 1996; Zouhiri et al., 1998). For example, Hesthagen (1973), Macquart-Moulin et al. (1987), and Zouhiri et al. (1998) all show different diel vertical migration patterns for BBL macrofauna. All of these studies clearly demonstrate that the selection pressure on this fauna varies in time and space, and among 
species. Though each species has its own behaviour, most suprabenthic species display a nocturnal emergency response to light extinction near the sea bottom (Ringelberg, 1995; Mees and Jones, 1997), which could be intrinsic to the species since diel migrations also occur at greater depths despite the lack of light changes throughout the day (Mees and Jones, 1997).

Along the French coast of the Eastern English Channel, running from the Bay of Somme to the southern Bay of the North Sea, a Phaeocystis bloom of variable intensity has occurred in the spring every year for several decades (1980), beginning at the earliest in the end of February and at the latest in June (Gypens et al., 2007). The presence of these gelatinous colonies modifies the viscosity (Seuront et al., 2006) and the transparency of the seawater, affecting the entire water column due to the mixed tidal regime in the eastern part of the Channel (Lagadeuc et al, 1997). Given these facts, the question is whether or not the change in light penetration in the water column has an effect on the suprabenthic community in areas affected by the spring Phaeocystis bloom.

The present study of the suprabenthic compartment is part of a larger five-year investigation (2001-2006) of the causes and consequences of the Phaeocystis bloom on the scale of the eastern English Channel. The results obtained for the suprabenthos during the 2002 campaigns (two stations, one coastal and one offshore), can be compared to a large data set from more than 500 suprabenthic hauls taken with a modified Macer-GIROQ sledge in the coastal zone of the English Channel (Vallet and Dauvin, 1998, 1999; Dauvin et al., 2000; Dauvin and Vallet, 2006), particularly two stations that were previously studied in May 1993 in the Dover strait (Fig. 1), respectively Station 5 on a pebble substrate $\left(50^{\circ} 54.50^{\prime} \mathrm{N}\right.$ $\left.1^{\circ} 34.00^{\prime} \mathrm{E}\right)$ and Station 6 on a medium sand substrate $\left(50^{\circ} 48.00^{\prime} \mathrm{N}-1^{\circ} 19.50^{\prime} \mathrm{E}\right)$ (Vallet, 1997 ; Vallet and Dauvin, 1998).

\section{Material and methods}

\subsection{Main aspects of the Phaeocystis bloom}

Phaeocystis is one of the most widespread marine haptophyte genus (Schoemann et al., 2005) and is exceptional not only for the very high carbon biomass values commonly attained by its monospecific blooms (up to $10 \mathrm{mg} \mathrm{C} .1^{-1}$ ), but also for its unique physiology, which has a serious impact on the structure and functioning of the pelagic and benthic food webs, as well as biogeochemical cycles (Lancelot and Rousseau, 1994; Janse et al., 1996; Hamm, 2000). The Phaeocystis genus has been studied extensively, and is characterized by a 
life cycle that alternates between free-living cells and gelatinous colonies. The latter produce large amounts of mucilaginous polysaccharides (Lancelot et al., 1994), which represent a large fraction of the overall colony biomass (Rousseau et al., 1990).

Due to the numerous and marked consequences on the coastal ecosystem, causes of variability in Phaeocystis blooms have been widely studied since several decades. Among them, nutrient enrichment and meteorological conditions have commonly been pointed out as key factors controlling the initiation and the intensity of Phaeocystis blooms. Even if the colony matrix might also give a competitive advantage to Phaeocystis when resources are scarce or highly fluctuating (Schoemann et al., 2001), the major contribution of anthropogenic eutrophication of coastal ecosystems to the bloom dynamics of this genus is well recognized (Lancelot et al., 1987). Based on a multi-box model, Gypens et al.(2007) have recently demonstrated the tight link between changing nutrient loads and Phaeocystis blooms in the Belgian coastal zone under direct and indirect influence of Scheldt and Seine inputs. They concluded that, in this area, Phaeocystis blooms are mainly controlled by nutrients, and suggested that only nitrogen reduction would result in significantly decreased Phaeocystis blooms without affecting diatoms, whereas further phosphorus load reductions would affect these two phytoplankton groups. Based on a long-term survey in the Wadden Sea, Cadée and Hegeman (2002) pointed out the first signs of a decrease in phytoplankton parameters, which might be consecutive to de-eutrophication. Moreover, they evidenced that since 1975, the start of Phaeocystis growth occurs earlier and they suggested a relationship with the higher spring temperatures consecutive to global warming.

All along the French coast of the English Channel, the nutrient-rich coastal water masses are recurrently affected by a massive Phaeocystis globosa spring bloom (Gypens et al., 2007), which seriously affects nutrient stock in the water column (Gentilhomme and Lizon, 1998; Schoemann et al., 2005), as well as the pelagic (Weisse et al., 1994; Verity, 2000; Stelfox-Widdicombe et al., 2004) and/or benthic food-webs (Vanaverbeke et al., 2004). In addition, the foam accumulation in intertidal areas leads to massive local macrofauna mortality (Desroy and Denis, 2004). [Although grazers could consume colonies and cells, a large proportion of the biomass produced by Phaeocystis enters the microbial food web after the colonies have disintegrated (Weisse et al., 1994; Brussaard et al., 1996)]. Furthermore, it has recently been hypothesized that rheological extracellular materials may modify the properties of seawater associated with colony formation and maintenance (Seuront et al., 2006). 


\subsection{Sampling site}

In 2002, two stations situated in a benthic transect opposite the mouth of the Canche estuary (Fig. 1) were selected for a study of the suprabenthos; both stations were located in the Ophelia borealis medium sand macrobenthic community found in the sand dunes that parallel the coast in this part of the English Channel (Dauvin and Dewarumez, 2000). The coastal (StC) and offshore (StO) stations were both located at depths of about $21 \mathrm{~m}$ at low tide (Table 1). The hydrological characteristics showed a temporal increase in the seawater temperature from March to June, and a lower salinity at StC than at StO due to the presence of the 'Fleuve côtier', a stream of low-salinity water masses along the coast (Brylinski et al., 1996). Nevertheless, an increase in salinity from March to June at StC could also be linked to the decrease of freshwater inputs by rivers, such as La Canche, during the spring.

Suprabenthos data were also available from six stations in the English Channel, situated in sediment ranging from medium sand to pebbles, sampled during a 'Le Suroît' CPB Manche cruise (May-June 1993) as part of the 'Programme National d'Océanographie Côtière' ((Vallet, 1997; Vallet and Dauvin, 1998). Among them, two stations in the Dover strait were studied in May 1993 (Fig. 1), respectively Station 5 on a pebble substrate $\left(50^{\circ} 54.50^{\prime} \mathrm{N}-1^{\circ} 34.00^{\prime} \mathrm{E}\right)$ at depths of $25 \mathrm{~m}$ and Station 6 on a medium sand substrate $\left(50^{\circ} 48.00^{\prime} \mathrm{N}-1^{\circ} 19.50^{\prime} \mathrm{E}\right)$ at depths of $29 \mathrm{~m}$.

\subsection{Sampling}

The Benthic Boundary Layer macrofauna was sampled with a Macer-GIROQ suprabenthic sledge (Dauvin et al., 1995), as was the case for the sample taken during the CPB Manche cruise (Vallet and Dauvin, 1998). Four $0.6 \mathrm{~m}$ wide boxes-each fitted with a WP2 plankton net $(0.5 \mathrm{~mm}$ mesh size $)$-were positioned one above the other at depths of 0.10-0.40 m (net 1), 0.45-0.75 m (net 2), 0.80-1.10 m (net 3) and 1.15-1.45 m (net 4) above the seabed. The net boxes were then towed against the tidal current for 5 minutes at a mean speed of 1.5 knots. A Tsurimi-Seiki Kosakusho (T.S.K.) flow meter in each box was used to measure the volume of the water filtered. The volume of water filtered through each net varied from 46 to $125 \mathrm{~m}^{3}$ (Table 1), and the mean volume of filtered water for the four net levels varied from 61 to $125 \mathrm{~m}^{3}$ (Table 1) with an overall mean of $88 \mathrm{~m}^{3}$.

During the period from March to June 2002 (Table 2), 19 hauls were collected during four campaigns, 15 at $\mathrm{StC}$ and 4 at $\mathrm{StO}$ (samples could not be taken at $\mathrm{StO}$ in April and June 
due to very bad meteorological conditions). At StC, sampling was done during each of the four cruises (Table 2). Due to the change in the number of daylight hours in spring, only one sample was taken during the day in March; otherwise, two daytime and two nighttime samples are available for the other sampling periods, except for the $20 \mathrm{~h} 00$ (8pm) haul taken in April, which is missing. For StC, a total of 7 daytime hauls and 8 nighttime hauls were taken. At StO, only one daytime sample and one nighttime sample are available for each date (Table 2). For station 5 and station 6, only the two daytime hauls and the two nighttime hauls taken in May 1993 were selected for comparison with the May 2002 samples.

The material collected was fixed with $10 \%$ neutral formalin on board immediately after samples retrieval. After about one week of storage, the material was washed and transferred to $70 \%$ ethanol. All suprabenthic individuals were sorted under a dissecting microscope, counted and identified to the species level whenever possible. The mean number of individuals in each haul was standardised to $100 \mathrm{~m}^{3}$. Light attenuation was measured during the day (at around 16h30) using a CTD recorder from the surface to $1 \mathrm{~m}$ above the sea bottom. To study the effect of light attenuation on the suprabenthos during the Phaeocystis bloom, only the lowest (Net 1) and the highest (Net 4) nets were considered, as they were judged sufficient to illustrate the vertical stratification in the Channel due to the high turbulence in such a megatidal sea (Dauvin et al., 2000).

\subsection{Statistical analysis}

In order to explain the relationships between the suprabenthic data from May 1993 and May 2002, the Bray-Curtis distance was calculated (Clarke and Warwick, 1994). A triangular similarity/distance matrix was created with Primer v5 (ㄷ E-Primer-Ltd), using the Bray Curtis value to indicate the similarity between the four sites ( $\mathrm{StC}$ and StO in May 2002 and St5 and St6 in May 1993). Then, a Hierarchical Cluster Analysis was performed using this similarity matrix, with the group average as the cluster mode. The resulting dendrograms were plotted.

The swimming activity of the dominant species ( $\mathrm{StC}$ ) was estimated using a $\mathrm{K}$ coefficient derived from an index proposed by Dauvin et al. (2000): K=N1/(N1+N4), with N1 number of individuals per $100 \mathrm{~m}^{3}$ in the lowest net (1) and $\mathrm{N} 4$ number of individuals per 100 $\mathrm{m}^{3}$ in the highest net (4) of the sledge. Then, to test temporal changes in swimming behaviour, the ratio between the mean abundance (N. ind. $100 \mathrm{~m}^{-3}$ ) at night and the mean abundance during the day (N. ind. $100 \mathrm{~m}^{-3}$ ) were calculated for the more abundant species recorded at StC. 


\section{Results}

\subsection{Fauna composition in spring 2002}

A total of 93 species were collected in 2002: 74 species at $\mathrm{StC}$ and 57 species at $\mathrm{StO}$, where the sampling effort was the lowest. Among these species, three peracarid groups formed $83 \%$ of the recorded species: amphipods (51 species), cumaceans (13 species) and mysids (13 species). The other groups were less diversified: pycnogonids (6), decapods (4 species) and isopods (4 species), tanaid (1 species) and leptostracean (1 species). These species had very low abundance values on all occasions $\left(<2\right.$ ind. $\left.100 \mathrm{~m}^{3}\right)$. So only the three dominant groups — amphipods, cumaceans, and mysids—-were considered for further analysis.

\subsection{Composition of the suprabenthic fauna}

Table 3 provides the species composition for the cumaceans, mysids and amphipods of the suprabenthos for four sampled stations in the Dover Strait. Amphipods dominated at all sites, followed by mysids, and then cumaceans. The number of species was related to the sampling effort (Dauvin et al., 2000), so St6 appears to be the richest station, especially in terms of amphipods, and $\mathrm{StC}$ seems to be the second richest station, probably due to the high number of samples taken at this station. With a similar sampling effort, the pebble substrate at St5 appears less diversified than the medium sand substrate at St6, but more diversified than $\mathrm{StO}$, where the lowest diversity was observed, probably due to the low number of samples taken at this station.

Table 4 gives the day/night mean abundances of the dominant species in May (1993 and 2002) at all four stations, for which a total of 92 species were recorded. The highest abundance appears at the coastal StC with five dominant species (N. ind. $100 \mathrm{~m}^{-3}>50$ at least in one station): two cumaceans, P. longicornis and P. similis; two mysids, Gastrosaccus spinifer and Schistomysis spiritus; and one amphipod, Atylus swammerdami. These species were also among the dominant species at the three other stations. High abundances of $G$. spinifer occurred at all four stations. Pseudocuma ssp. was abundant only in 2002, while two other cumaceans were among the three dominant species at the different stations: Bodotria scorpioides at St5 and St6 and Diastylis bradyi at StC and StO. Acanthomysis longicornis was abundant at St6 and StO, and five other mysids (Table 4) with the lowest abundances were collected only at one of the four stations. Among the amphipods, Apherusa ovalipes was 
abundant in 2002 at StO and less abundant at StC, while Stenothoe marina showed moderate abundances at all four sites in 1993 and in 2002. On the contrary, Apherusa clevei and Metopa borealis were only abundant in 1993. Megaluropus agilis was among the dominant species, except at St5. Three other amphipods were among the dominant species at only one station (Table 4). In addition, three littoral Bathyporeia species-B. pelagica, B. pilosa and B. sarsi-were recorded in low abundance at StC, but this simply indicates the influence of the littoral fauna in this station; at the three offshore stations, as could be expected, more marine species were sampled.

Figure 2 shows the Bray-Curtis similarity among the four May samples in terms of species richness (Fig. 2a) and abundance (Fig. 2b), excluding rare species (i.e., species found at only one station, numbering 38 of the 92 species recorded in May). For both the richness and abundance analyses, two groups appear: group 1 contains St5 and St6, and group 2 contains StC and StO. This separation could be the result of: i) a temporal effect, since the sampling was performed during two different years, respectively 1993 and 2002, ii) the spatial proximity of the two stations in each group, $\mathrm{St} 5$ and St6 in the Dover Strait and StC and StO opposite the Canche estuary, or iii) the particular species composition of the different communities at the stations. Clearly, the medium sand community opposite the Canche estuary is in an area of dominated by soft-bottom sediment, while the Dover Strait is dominated by hard bottoms, which favour certain vagile species, such as the amphipods Erichtonius puncatus, Iphimedia spp. (five species) that were collected. On the other hand, the amphipods Atylus falcatus, Melita palmata, Pariambus typicus and Bathyporeia spp. (four species) were collected only in the stations opposite the Canche estuary. Still, the affinity (> 50) between the four stations is high: there are 28 common species, with St5 and St6 sharing 21 species, and $\mathrm{StC}$ and $\mathrm{StO}$ sharing five species. The total abundance in May is the lowest on the pebble substrate at station St5; the offshore stations St6 and StO show similar average levels of total abundance, while the station StC has the highest abundance (Table 4).

In summary, the four stations show comparable species composition on the scale of the eastern Channel with the dominance of a very low number of species, including four amphipods (Apherusa spp., Atylus swammerdami, Megaluropus agilis and Stenothoe marina), two cumaceans (Pseudocuma longicornis and P. similis) and one mysid (Gastrosaccus spinifer). Abundance values demonstrate a decreasing coastal-offshore gradient.

\subsection{Temporal changes in spring 2002}


Figure 3 shows the differences in species richness (Fig. 3a) and abundance (Fig. 3b) between March and May for both the StC and StO stations during the day and at night. Three main points can be underlined: i) there is a temporal increase in species richness and abundance between the two dates; ii) in March, before the bloom, daytime abundances were lower than nighttime abundances, providing evidence of a nocturnal emergency amoung suprabenthic species; and iii) in May, during the bloom, the abundances of the cumaceans and mysids at StC were of the same magnitude during the day and night, showing that the swimming activity of these suprabenthic species occurred throughout the entire 24-hour time period.

\subsection{Swimming activity at the coastal station (StC) in spring 2002}

The $\mathrm{K}$ ratio of 26 species was calculated for each of the four dates from the 2002 sampling. Figure 4 shows the temporal distribution of Kmax (low swimming activity, the abundance in net 1 being higher than in net 4) and the Kmin (high swimming activity, the abundance in net 4 being sometimes similar to that of net1). It appears that the Kmin and Kmax frequencies were close to the mean (25\%) in March and April, then the Kmin value was higher than the mean in May, and lower than the mean in June, indicating acute changes in swimming behaviour between the two last months, probably due to the maximum level of the Phaeocystis bloom that occurred in May.

Figure 5 gives the monthly night/day abundance ratios from March to June for 12 principal species. Four main patterns can be identified:

i) Three abundant species-Gastrossacus spinifer, Pseudocuma longicornis and Stenothoe marina-were affected over time by light attenuation during the Phaeocystis bloom and showed low ratios in April and May (with similar abundance values for both night and day) compared to those observed before the bloom in March and after the bloom in June;

ii) Three species with low average abundances-Acanthomysis longicornis, Schistomysis spiritus and Apherusa ovalipes - underwent a sharp increase in the night/day abundance ratio in May, probably due to a nuptial emergency during this spring month;

iii) Four species-Megaluropus agilis (abundant), Pontocrates arenarius (rare), Pseudocuma similis (very abundant) and Orchemene nana (moderate abundance)—underwent a sharp increase in the night/day abundance ratio in June, probably due to a nuptial emergency during this last month of spring; 
and iv) Two abundant species-Diastylis bradyi and Atylus swammerdami-showed a sharp decrease in abundance and a slight change in the night/day abundance ratio, respectively, over time.

\section{Discussion}

The suprabenthic fauna of the entire English Channel appears relatively homogeneous at a meso-scale level and can be considered as a single community including three kinds of species (Dauvin et al., 2000): i) good swimmer species that are common at all times and at all sites (e.g. Gastrosaccus spp. and Apherusa spp.) ; ii) species that are present at all sites but only at night (e.g., Atylus spp., Megaluropus agilis, Orchonene nana, and Pseudocuma longicornis), and iii) species occupying one or a limited number of sites at night, and at StC, according to the nature of the macrobenthic fauna (e.g., Bathyporeia spp.).

The complete control mechanisms of the diel vertical migration behaviour in the suprabenthos remain poorly understood. Nevertheless, a synthesis of previous works (see Mees and Jones, 1997; Dauvin et al., 2000; Dauvin and Vallet, 2006) indicates that swimming activity near the sea floor, especially in marine coastal environments, increase at two particular moments: sunrise and sunset. Changes in light intensity have been recognized as the most important factor in determining the migratory activities of suprabenthic species (Hestagen, 1973; Macquart-Moulin et al., 1987; Zouhiri and Dauvin, 1995; Mees and Jones, 1997; Zouhiri et al., 1998; Dauvin et al., 2000). Han and Straskraba (1998) showed that both light and predation pressure play a central role in regulating such diel vertical migrations. Consequently, these migrations of suprabenthos are a general phenomenon showing an increase of abundance at night in the Benthic Boundary Layer just after sunset and a re-entry into the sea bottoms just after sunrise. In coastal environments, this pattern is clearly a response to light intensity attenuation near the sea bottoms after sunset (see Macquart-Moulin et al., 1987). But, in areas with high turbidity and, consequently, very slight changes in the amount of light (e.g., the Seine estuary), no daily migrations have been observed (Mouny et al., 2000; Dauvin and Vallet, 2006).

Numerous authors (Williamson and Magnien, 1982; Ohman, 1990; Bollens and Frost, 1991; Macquart-Moulin, 1999; Arashkevich et al., 2002) have observed a correlation between feeding rhythm and diel vertical migration. This could explain similar diel migrations observed in the English Channel of meso- and macrozooplankton: chaetognaths, euphausids and fish larvae, which feed essentially on the copepods that essentially constitute 
macrozooplankton (Wang and Dauvin, 1994; Vallet and Dauvin, 2001, 2004). Bollens and Frost (1989) observed variation in the diel vertical migration of the copepod Calanus pacificus in response to the abundance of visual predators in a temperate fjord. These authors affirmed that such behavioural flexibility might signal many cases of diel vertical migration in which the behaviour is seasonally or geographically variable.

The intensity and duration of Phaeocystis blooms is clearly linked to coastal eutrophication (Gypens et al., 2007), through riverine nutrient loads (nitrogen, phosphorus) of which temporal variability depends on meteorological conditions (wet or dry period). Morever, it is well known that phytoplankton blooms, especially those of Phaeocystis, increase turbidity and light attenuation, most especially when Phaeocystis form dense colonies (Peperzak et al., 2000). Consequently, in the nutrient-rich and megatidal English Channel, where high turbulence levels result in high levels of mixing, the whole water column is widely affected by these bloom-provoked perturbations. Measurements of light intensity in the water column (Fig. 6) show that light attenuation near the sea floor was higher at StC than at StO, and lower in April and May than in March and June (StC). Consequently, light attenuation was higher during the Phaeocystis bloom than before and after this phenomenon.

The Phaeocystis bloom event had a limited effect on suprabenthic composition (species richness and abundance values) as shown by the strong similarity between data and the fauna sampled in May 1993 at two offshore stations unaffected by the Phaeocystis bloom in the Dover Strait (Vallet, 1997; Vallet and Dauvin, 1998). Such a limited effect was also observed on subtidal macrobenthic Ophelia medium sand and the Amphioxus lanceolatus coarse sand communities sampled during the same sampling period (March-June 2002) (Denis and Desroy, in preparation). On the shallow Abra alba community, the effect of the bloom was characterized by a significant increase in mineralization processes, as evidenced by higher Sediment Oxygen Demand and higher ammonium releases. In the intertidal communities around the Canche estuary, foam deposits have been shown to have drastic consequences on benthic fauna, leading to massive mortality at the impacted sites. Sandy sediments were less impacted, and showed the rapid recovery of the macrofaunal communities, whereas in muddy sediments, all taxa were affected, and full recovery still had not occurred even after several months (Desroy and Denis, 2004).

However, the present study clearly shows that the Phaeocystis bloom affects the diel migrations of some dominant species, such as the cumaceans Pseudocuma longicornis and $P$. similis, the mysid Gastrosaccus spinifer and the amphipod Stenothoe marina. Subsequently, during the bloom, their diurnal and nocturnal abundances in the water column were similar, 
whereas in the absence of bloom, species remained benthic during the day and suprabenthic the night. It is interesting to note that these species have been classified among the lower and lowermost suprabenthic species (low swimming activities) (Dauvin et al., 2000); conversely, species such as the mysids Acanthomysis longicornis, Schistomysis spiritus and Apherusa ovalipes with strong swimming activities (Dauvin et al., 2000) showed no behavioural responses to light attenuation during the Phaeocystis bloom. Such migratory activity increases the transfer of live organic matter between the sea bottom and the Benthic Boundary Layer (Vallet and Dauvin, 2001). Mobility may also have a negative effect by increasing the exposure of suprabenthos fauna to predators (Jørgensen and Christie, 2003). The permanent presence of suprabenthic species in the benthic boundary layer could increase their predation by fish, especially juveniles, which preferentially consume small crustaceans in their diet (Wang and Dauvin, 1994; Mees and Jones, 1997; Jørgensen and Christie, 2003).

In his predator evasion hypothesis, Hays (2003) underlined that normal diel vertical migration of zooplankton reduces the risk of predation from visual predators. Fish that require high ambient light levels to locate and capture prey may be unable to feed on suprabenthos at night. In some areas of the Channel, such as offshore of Roscoff (Zouhiri and Dauvin, 1995) and in the eastern part of the Bay of Seine (Wang and Dauvin, 1994), a sinking of fish juveniles, such as clupeids and gobies, has been observed at sunset and sunrise, probably at the moment of emergency, with re-entry of the suprabenthos species into the sea bottoms only when light intensity remains sufficient to capture their prey. Exposure to fish predation may be reduced if suprabenthos dispersal takes place mainly at night (Jørgensen and Christie, 2003). So, it is probable that light attenuation near the sea bottom in the daytime during the Phaeocystis bloom has the same consequences that nightfall has: provocation of suprabenthic species emergencies and modification of their swimming activity. Still, fish predation, especially by visual predators, could be itself disturbed by changes in light intensity. In proof of this hypothesis, an effect on plaice growth during Phaeocystis bloom has been observed in the Canche estuary, possibly due to poor nutrition during years with abundant Phaeocystis bloom (Selleslagh and Amara, 2007). Such a hypothesis could be verified in the future, probably on the base of experimental studies.

\section{Acknowledgements}

This study was carried out as a part of the Programme National d'Environnement Côtier (PNEC) co-ordinated by IFREMER and CNRS within the framework of the Contrat de 
Plan Etat-Région (CPER) 'Perturbed littoral Ecosystems' program co-ordinated by the Nord/Pas-de-Calais Region. The authors would like to thank Antoine Meirland, Karine Randriambao, and Benoit Ward for their help during the campaigns and in the laboratory, Valerie Gentilhomme for her coordination of both the CPER and PNEC Phaeocystis programs, and Lisa Ellen Spencer Services for help with the English version of this paper.

\section{References}

Arashkevich, E.G., Wassmann, P., Pasternak, A. \& Wexels Riser, C., 2002. Seasonal and spatial changes in biomass, structure and development progress of the zooplankton community in the Barents Sea. Journal of Marine Systems 38, 125-145.

Bollens, S. M., Frost, B. W., 1991. Diel vertical migration in zooplankton: rapid individual response to predators. Journal of Plankton Research 13, 1359-1365.

Brunel, P., Besner, M., Messier, D., Poirier, L., Granger, D., Weinstein, M., 1978. Le traîneau Macer-GIROQ : appareil amélioré pour l'échantillonnage quantitatif de la petite faune nageuse au voisinage du fond. Internationale Revue der Gesamten Hydrobiologie 63, 815829.

Brussaard, C.P.D., Gast, G.J., Van Duyl, F.C., Riegman, R., 1996. Impact of phytoplankton bloom magnitude on a pelagic microbial food web. Marine Ecology Progress Series 144, 211 221.

Brylinski, J.M., Brunet, C., Bentley, D., Thoumelin, G., Hilde, D., 1996. Hydrography and phytoplankton biomass in the Eastern English Channel in spring 1992. Estuarine and Coastal Shelf Science 43, 507-519.

Cadée, G.C., Hegeman, J., 2002. Phytoplankton in the Marsdiep at the end of the 20th century; 30 years monitoring biomass, primary production, and Phaeocystis blooms. Journal of Sea Research 48, 97-110.

Chekley, D.M., Uye, S., Dagg, M.J., Mullin, M.M., Omori, M., Onbé, T., Zhu, M.Y., 1992. Diel variation of the zooplankton and its environment at neritic stations in the Inland Sea of Japan and the north-west Gulf of Mexico. Journal of Plankton Research 14, 1-40.

Clarke, K.R., Warwick, R.M., 1994. Change in marine communities: an approach to statistical analysis and interpretation. Plymouth Marine Laboratory, Natural Environment Research Council, 144pp.

Dauvin, J.C., Sorbe, J.C., Lorgeré, J.C, 1995. The Benthic Boundary Layer macrofauna from the upper continental slope and the Cap-Ferret Canyon (Bay of Biscay). Oceanologica Acta $18,113-122$. 
Dauvin, J.C., Zouhiri, S., 1996. Suprabenthic fauna of a dense Ampelisca community from the English Channel. Journal of the Marine Biological Association of the United Kingdom 76, 909-929.

Dauvin, J.C., Vallet, C., Mouny, P., Zouhiri, S., 2000. Main Characteristics of the Boundary Layer macrofauna in the English Channel. Hydrobiologia 426, 139-156.

Dauvin, J.C., Dewarumez, J.M., 2002. Patrimoine naturel de la Manche Orientale et du sud de la mer du Nord : invertébrés benthiques et peuplements macrobenthiques sublittoraux. Actes du Colloque 'Qualité des eaux : objectifs atteints, Wimille A.B.E.P. 7 décembre 2000, 9-27.

Dauvin, J.C. \& Vallet, C., 2006. The near bottom layer as an ecological boundary in marine ecosystems: diversity, taxonomic composition and community definitions. Hydrobiologia 555, 49-58.

Denis, L., Desroy, N., Consequences of spring phyto-detritus sedimentation on the benthic compartment along the depth gradient in the Eastern English Channel. Marine Pollution Bulletin (in preparation).

Desroy, N., Denis, L., 2004. Influence of spring phytodetritus sedimentation on intertidal macrozoobenthos in the eastern English Channel. Marine Ecology Progress Series, 270: 4153.

Fosså, J.H., Brattegard, T., 1990. Bathymetric distribution of Mysidacea in fjords of western Norway. Marine Ecology Progress Series 67, 7-18.

Gentilhomme, V., Lizon, F., 1998. Seasonal cycle of nitrogen and phytoplankton biomass in a well-mixed coastal system (Eastern English Channel). Hydrobiologia 361, 191-199.

Gypens, N., Lacroix, G., Lancelot, C., 2007. Causes of variability in diatom and Phaeocystis blooms in Belgian coastal waters between 1989 and 2003: A model study. Journal of Sea Research 57, 19-35.

Hamm, C.E., 2000. Architecture, ecology and biogeochemistry of Phaeocystis colonies. Journal of Sea Research 43, 307-315.

Han B.P., Straskraba M., 1998. Modelling patterns of zooplankton diel vertical migration Journal of Plankton Research 20,1463-1487.

Hays, G.C., 2003. A review of the adaptative significance and ecosystem consequences of zooplankton diel vertical migrations. Hydrobiologia 503, 163-170.

Hesthagen, I.H., 1973. Diurnal and seasonal variations in the near-bottom fauna -the hyperbenthos in one of the deeper channels of the Kieler Bucht (Western baltic). Kieler Meeresforschung 29, 116-140. 
Janse, J., van Rijssel, M., Gottschal, J.C., Lancelot, C., Gieskes, W.W.C., 1996. Carbohydrates in the North Sea during spring blooms of Phaeocystis: a specific fingerprint. Marine Ecology Progress Series 10, 97-103

Jørgensen, N.M., Christie, H., 2003. Diurnal, horizontal and vertical dispersal of kelpassociated fauna. Hydrobiologia 503, 69-76.

Lagadeuc, Y., Brylinski, J.M., Aelbrecht, D., 1997. Temporal variability of the vertical stratification of a front in a tidal Region Of Freshwater Influence ( ROFI) system. Journal of Marine Systems 12, 147-155.

Lancelot, C., Billen, G., Sournia, A., Weisse, T., Colijn, F., Veldhuis, M.J.W., Davies, A., Wassman, P., 1987. Phaeocystis blooms and nutrient enrichment in the continental coastal zones of the North Sea. Ambio 16, 38-46.

Lancelot, C., Rousseau, V., 1994. Ecology of Phaeocystis: the key role of colony forms. In: Green, J.C., Leadbeater, B.S.C. (Eds.), The haptophyte Algae. Clarendon Press, Oxford, UK, p. $229-245$.

Lancelot, C., Wassmann, P., Barth, H., 1994. Ecology of Phaeocystis-dominated ecosystems. Journal of Marine Systems 5, 1-4.

Longhurst, A.L., 1976. Vertical migration. In: Cushing, D.H., Walsh, J.J. (Eds.), The ecology of the seas. Blackwell, Oxford, p. 116-137.

Macquart-Moulin, C., Bourdillon, A., Cubizolles, F., Passelaige, F., Rasoanarivo, R., 1987. Un cas typique de migration verticale retard chez l'amphipode Ampelisca typica. Journal of Plankton Research 9, 785-809.

Macquart-Moulin, C., 1999. Diel vertical migration and endogenous swimming rhythm in Asterope mariae (Baird) and Philomedes interpuncta (Baird) (Crustacea Ostracoda Cypridinidae). Journal of Plankton Research 21, 1891-1910.

Mees, J., Jones, M., 1997. The hyperbenthos. Oceanography and Marine Biology: an Annual Review 35: 221-255.

Mouny, P., Dauvin, J.C., Zouhiri, S., 2000. Benthic Boundary Layer fauna from the Seine estuary (eastern English Channel): spatial distribution and seasonal changes. Journal of the Marine Biological Association of the United Kingdom 80, 959-968.

Ohman, M.D., Frost, B.W., Cohen, E.H., 1983. Reverse diel vertical migration - an escape from invertebrate predators. Science 220, 1404-1407.

Ohman, M.D., 1990. The demographic benefits of diel vertical migration by zooplankton. Ecological Monography, 60, 257-281. 
Peperzak, L., Colijn, F., Gieskes, W.W.C., Peeters, J.C.H., 1998. Development of the diatomPhaeocystis spring bloom in the Dutch coastal zone of the North Sea: the silicon depletion versus the daily irradiance threshold hypothesis. Journal of Plankton Research 20, 517-537.

Peperzak, L., Colijn, F., Peeters, J.C.H., 2000. Observations of flagellates in colonies of Phaeocystis globosa (Prymnesiophyceae); a hypothesis for their position in the life cycle. Journal of Plankton Research 22, 2181-2203.

Ringelberg, J., 1995. Changes in light intensity and diel vertical migration - a comparison of marine and fresh-water environments. Journal of Marine Biological Association of the United Kingdom 75, 15-25.

Rousseau, V., Mathot, S., Lancelot, C., 1990. Calculating carbon biomass of Phaeocystis sp. from microscopic observations. Marine Biology 107, 305- 314.

Schoemann, V., Wollast, R., Chou, L., Lancelot, C., 2001. Effects of photosynthesis on the accumulation of Mn and Fe by Phaeocystis colonies. Limnology and Oceanography 46, 10651076.

Schoemann, V., Becquevort, S., Stefels, J., Rousseau, V., Lancelot, C., 2005. Phaeocystis blooms in the global ocean and their controlling mechanisms: a review. Journal of Sea Research 53, 43-66.

Selleslagh, J., Amara, R., 2007. Influence of Phaeocystis globosa bloom upon settlement and biological performances of plaice Pleuronectes platessa in the eastern English Channel. Phaeocystis bloom: causes and consequences (PBCC). Recommended practices and future directions - PNEC meeting, Wimereux 29-30 January 2007, abstract 14.

Seuront, L., Vincent, D., Mitchell, J.G., 2006. Biologically induced modification of seawater viscosity in the Eastern English Channel during a Phaeocystis globosa spring bloom. Journal of Marine Systems 61, 118-133.

Stelfox-Widdicombe, C.E., Archer, S.D., Burkilla, P.H., Stefels, J., 2004. Microzooplankton grazing in Phaeocystis and diatom-dominated waters in the southern North Sea in spring. Journal of Sea Research 51: 37-51.

Vallet, C., 1997. Le compartiment suprabenthique des fonds circalittoraux de la Manche : composition faunistique et quantitative, et rôle dans les transferts benthos/pélagos. Phd Thesis, Pierre and Marie Curie (Paris VI) university, 160 pp.

Vallet, C., Dauvin, J.C., 1998. Composition and diversity of the Benthic Boundary Layer macrofauna from the English Channel. Journal of the Marine Biological Association of the United Kingdom 78, 387-409. 
Vallet, C., Dauvin, J.C., 1999. Seasonal changes of macrozooplankton and Benthic Boundary Layer macrofauna from the Bay of Saint Brieuc (western English Channel). Journal of Plankton Research 21, 35-49.

Vallet, C., Dauvin, J.C., 2001. Biomass changes and bentho-pelagic transfers throughout the Benthic Boundary Layer in the English Channel. Journal of Plankton Research 23, 903-922.

Vallet, C. \& Dauvin, J.C. 2004. Spatio-temporal changes of the near-bottom mesozooplankton from the English Channel. Journal of the Marine Biological Association of the United Kingdom 84, 539-546.

Vanaverbeke, J., Steyaert, M., Soetaert, K., Rousseau, V., Van Gansbeke, D., Parent, J.Y., Vincx, M., 2004. Changes in structural and functional diversity of nematode communities during a spring phytoplankton bloom in the southern North Sea. Journal of Sea Research 52: 281-292.

Verity, P.G., 2000. Grazing experiments and model simulations of the role of zooplankton in Phaeocystis food webs. Journal of Sea Research 43, 317-343.

Wang, Z., Dauvin, J.-C., 1994. The suprabenthic crustacean fauna of the infralittoral fine sand community from the Bay of Seine (Eastern English Channel): composition, swimming activity and diurnal variation. Cahiers de Biologie Marine 35, 135-155.

Weisse, T., Tande, K., Verity, P., Hansen, F., Gieskes, W., 1994. The trophic significance of Phaeocystis blooms. Journal of Marine Systems 5, 67-79.

Williamson, C. E. \& R. E. Magnien, 1982. Diel vertical migration in Mesocyclops edax: implications for predation rate estimates. Journal Plankton Research 4, 329-339.

Zouhiri, S., Dauvin, J.C., 1995. Diel changes of the Benthic Boundary Layer macrofauna over coarse sand sediment in the western English Channel. Oceanologica Acta 19: 141-153.

Zouhiri, S., Vallet, C., Mouny, P. \& Dauvin, J.C., 1998. Spatial distribution and biological rhythms of suprabenthic mysids from the English Channel. Journal of the Marine Biological Association of the United Kingdom 78, 1181-1202. 
Fig. 1. Map of the studied area in the eastern part of the Channel.

Fig. 2. Dendrogram, with group average as the cluster mode, showing the Bray Curtis similarity on species richness (a) and abundance (N. ind. $100 \mathrm{~m}^{-3}$ ) in May (1993 and 2002) for the four stations in the eastern English Channel, excluding the rare species that were found in only one station.

Fig 3. Day and night species richness and abundance (N. ind. $100 \mathrm{~m}^{-3}$ ) values for cumacea, amphipoda and mysidacea in March (before the Phaeocystis bloom) and May 2002 (during the bloom) at both stations: StC (coastal station) and StO (offshore station).

Fig 4. Frequency of the K swimming activity ratio at StC from March to June 2002.

Fig. 5. Ratio (N/D) between mean nighttime abundance (N. ind. $100 \mathrm{~m}^{-3}$ ) and mean daytime abundance (N. ind. $100 \mathrm{~m}^{-3}$ ) from March to June 2002 at the coastal station StC for 12 main species.

Fig. 6. Light intensity near the sea bottom $\left(\mu \mathrm{Em}^{-2} \cdot \mathrm{s}^{-1}\right)$ at the coastal station $(\mathrm{StC})$ and the offshore station (StO) from March to June 2002, with a close-up of the Benthic Boundary Layer (1-2 m). 
Table 1. M ain characteristics of the hydrological conditions in both stations (coastal, StC and offshore, St0) from M arch to J une 2002.

\begin{tabular}{|c|c|c|c|c|c|c|c|c|c|c|c|c|}
\hline & \multicolumn{8}{|c|}{ StC } & \multicolumn{4}{|c|}{ Sto } \\
\hline Location & \multicolumn{8}{|c|}{$50^{\circ} 32.00^{\prime} \mathrm{N}-1^{\circ} 30.00^{\prime} \mathrm{E}$} & \multicolumn{4}{|c|}{$50^{\circ} 36.00^{\prime} \mathrm{N}-1^{\circ} 04.00^{\prime} \mathrm{E}$} \\
\hline Depth & \multicolumn{8}{|c|}{$21.1 \mathrm{~m}$} & \multicolumn{4}{|c|}{$21.6 \mathrm{~m}$} \\
\hline Substratum & \multicolumn{12}{|c|}{ Clean medium sand 0 phelia borealis community } \\
\hline \multirow{2}{*}{ Dates } & \multicolumn{2}{|c|}{$15 \mathrm{M}$ arch } & \multicolumn{2}{|c|}{11 A pril } & \multicolumn{2}{|c|}{$10 \mathrm{M}$ ay } & \multicolumn{2}{|c|}{4 June } & \multicolumn{2}{|c|}{$16 \mathrm{M}$ arch } & \multicolumn{2}{|c|}{12 M ay } \\
\hline & Day & Night & Day & Night & Day & Night & Day & Night & Day & Night & Day & Night \\
\hline Temperature & 8.25 & 7.91 & 9.80 & 9.76 & 11.24 & 11.30 & 13.85 & 14.12 & 9.09 & 9.04 & 11.08 & 11.11 \\
\hline Salinity & 33.18 & 32.03 & 34.13 & 34.01 & 34.27 & 34.11 & 34.38 & 34.09 & 35.00 & 34.93 & 34.93 & 34.92 \\
\hline
\end{tabular}


Table 2. Main characteristics of the Macer-GIROQ sampling during the March-J une 2002 campaign (Hour U.T .: Hour in U niversal Time, D: day; N: night; -: no data for filtered water volume due to a malfunction of the TSK flow meter; the data for N et 1 and Net 4 are in bold)

\begin{tabular}{|c|c|c|c|c|c|c|c|c|}
\hline \multirow{2}{*}{ Date } & \multirow{2}{*}{ Site } & \multirow{2}{*}{$\begin{array}{l}\text { Hour } \\
\text { U.T. }\end{array}$} & \multirow{2}{*}{$\mathrm{D} / \mathrm{N}$} & \multicolumn{4}{|c|}{ V olume of filtered water $\left(\mathrm{m}^{3}\right)$} & \multirow{2}{*}{$\begin{array}{l}\text { M ean volume of filtered } \\
\text { water }\left(m^{3}+/-s d\right)\end{array}$} \\
\hline & & & & Net 1 & Net 2 & Net 3 & Net 4 & \\
\hline \multirow{4}{*}{$15 \mathrm{M}$ arch } & $\mathrm{C}$ & 16h17 & $\mathrm{D}$ & 89 & 88 & 101 & 107 & $96.4+/-9.2$ \\
\hline & $\mathrm{C}$ & 18h02 & $\mathrm{N}$ & - & - & 124 & 125 & $124.7+/-0.5$ \\
\hline & C & 21h09 & $\mathrm{N}$ & 86 & 82 & 102 & 109 & $94.7+/-13.1$ \\
\hline & $\mathrm{C}$ & $22 \mathrm{~h} 57$ & $\mathrm{~N}$ & - & - & 87 & 85 & $86.2+/-1.7$ \\
\hline \multirow{2}{*}{$16 \mathrm{M}$ arch } & 0 & $16 h 25$ & $\mathrm{D}$ & - & 108 & 75 & 118 & $100.4+/-22.3$ \\
\hline & 0 & $22 h 59$ & $\mathrm{~N}$ & 46 & 50 & 77 & 72 & $61.0+/-15.6$ \\
\hline \multirow{3}{*}{11 A pril } & $\mathrm{C}$ & 15h31 & $\mathrm{D}$ & 84 & 79 & 91 & - & $84.5+/-6.2$ \\
\hline & C & 17h00 & $\bar{D}$ & - & 80 & 94 & - & $87.4+/-10.0$ \\
\hline & $\mathrm{C}$ & $21 h 48$ & $\mathrm{~N}$ & 63 & 81 & 77 & - & $73.8+/-9.3$ \\
\hline \multirow{4}{*}{10 M ay } & C & $15 h 25$ & $\mathrm{D}$ & - & 75 & - & - & 75.2 \\
\hline & $\mathrm{C}$ & 16h57 & $\bar{D}$ & 73 & 72 & 82 & - & $75.5+/-5.7$ \\
\hline & $C$ & 20h02 & $\mathrm{N}$ & 83 & 68 & 74 & - & $75.2+/-7.6$ \\
\hline & $C$ & $21 h 59$ & $\mathrm{~N}$ & - & 73 & 78 & 77 & $76.0+/-2.8$ \\
\hline \multirow{2}{*}{12 M ay } & 0 & $14 h 59$ & $\mathrm{D}$ & - & 75 & - & - & 75.2 \\
\hline & 0 & $22 \mathrm{~h} 06$ & $\mathrm{~N}$ & 118 & 123 & 126 & 110 & $119.4+/-6.8$ \\
\hline \multirow{4}{*}{4 J une } & $C$ & 15h38 & $\mathrm{D}$ & 86 & 89 & 93 & - & $89.4+/-3.7$ \\
\hline & $C$ & $17 \mathrm{~h} 25$ & $\mathrm{D}$ & 73 & 80 & 73 & 80 & $76.1+/-3.9$ \\
\hline & $C$ & 19h59 & $\mathrm{N}$ & 89 & 88 & 90 & 92 & $89.7+/-1.5$ \\
\hline & $\mathrm{C}$ & 21h55 & $\mathrm{N}$ & 109 & 124 & 114 & 123 & $117.5+/-7.0$ \\
\hline
\end{tabular}


Table 3. Composition of the suprabenthos in M ay 1993 (stations 5 and 6 from V allet, 1997) and in spring 2002 at both stations: StC and StO.

\begin{tabular}{|l|c|c|c|c|}
\hline Stations & St5 & St6 & StC & St0 \\
\hline Depth in $\mathrm{m}$ & 25 & 29 & 21 & 21 \\
\hline Substratum & Pebble & \multicolumn{3}{|c|}{ M edium sand } \\
\hline Number of nets & 20 & 20 & 30 & 8 \\
\hline Cumaceans & 6 & 7 & 8 & 5 \\
\hline M ysids & 9 & 9 & 12 & 9 \\
\hline A mphipods & 38 & 53 & 44 & 35 \\
\hline Total & 53 & 69 & 64 & 49 \\
\hline
\end{tabular}


Table 4. Dominant species in M ay 1993 (stations 5 and 6 from V allet, 1997) and in M ay 2002 (stations StC and StO), for the three main species of cumaceans and mysids and the five main species of amphipods, all the data in mean numbers of individuals per $100 \mathrm{~m}^{3}$ (Day/night mean).

\begin{tabular}{|c|c|c|c|c|}
\hline Species/Stations & St5 & St6 & StC & StO \\
\hline \multicolumn{5}{|l|}{ C umaceans } \\
\hline Pseudocuma similis & 0.2 & 2.0 & 248.9 & 9.9 \\
\hline Pseudocuma longicornis & 0.2 & 0.3 & 131.9 & 19.4 \\
\hline Bodotria scorpioides & 2.1 & 3.9 & - & - \\
\hline Diastylis bradyi & - & - & 6.0 & 0.8 \\
\hline \multicolumn{5}{|l|}{ Mysids } \\
\hline Gastrosaccus spinifer & 54.0 & 158.9 & 436.1 & 290.8 \\
\hline Schistomysis spiritus & - & - & 115.3 & - \\
\hline Acanthomysis longicornis & - & 4.6 & - & 20.8 \\
\hline Anchialina agilis & 4.6 & - & - & - \\
\hline Paramysis helleri & - & - & 5.9 & - \\
\hline Schistomysis kervellei & 6.8 & - & - & - \\
\hline Schistomysis ornata & - & 3.7 & - & - \\
\hline Mysidopsis gibbosa & - & - & - & 3.7 \\
\hline \multicolumn{5}{|l|}{ Amphipods } \\
\hline Atylus swammerdami & 18.6 & 14.8 & 257.3 & 64.3 \\
\hline Stenothoe marina & 27.5 & 45.6 & 7.2 & 6.3 \\
\hline Apherusa clevei & 8.2 & 20.6 & - & - \\
\hline M etopa borealis & 7.9 & 20.0 & - & - \\
\hline Ischyrocerus anguipes & 5.9 & - & - & - \\
\hline M egaluropus agilis & - & 7.7 & 36.9 & 15.1 \\
\hline Apherusa ovalipes & - & - & 26.4 & 99.4 \\
\hline Atylus falcatus & - & - & 4.1 & - \\
\hline Apherusa bispinosa & - & - & - & 5.4 \\
\hline Total abundance & 168 & 317 & 1332 & 555 \\
\hline
\end{tabular}


Figure 1
Click here to download high resolution image

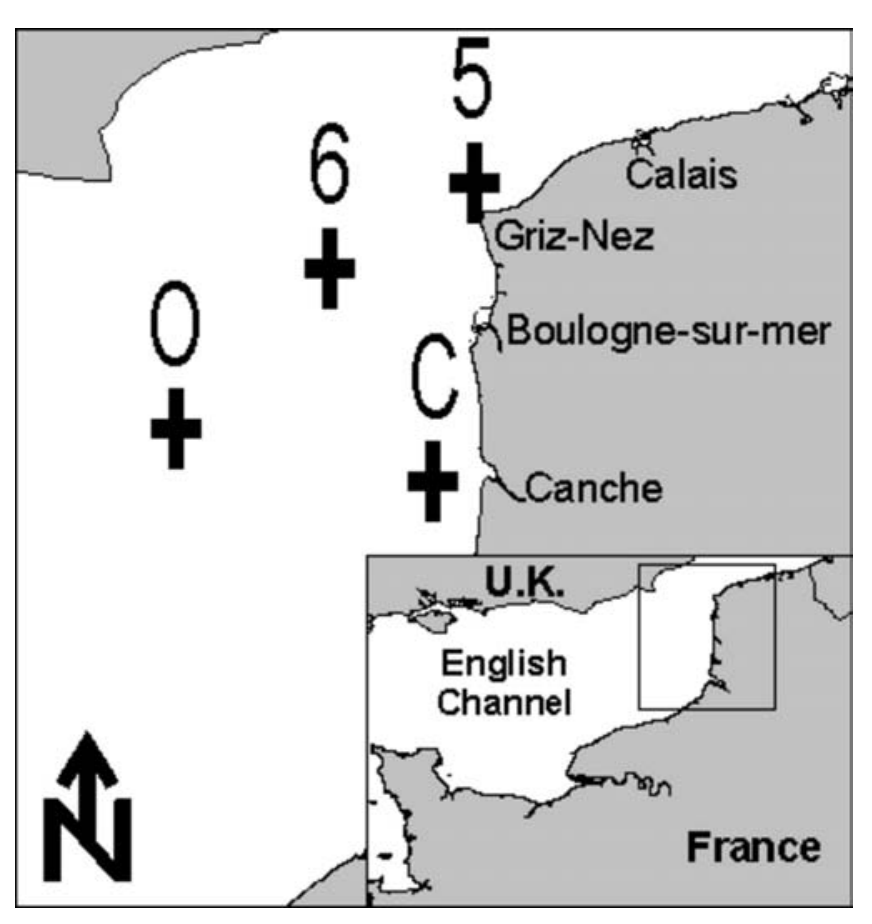


Click here to download high resolution image

a) Species richness

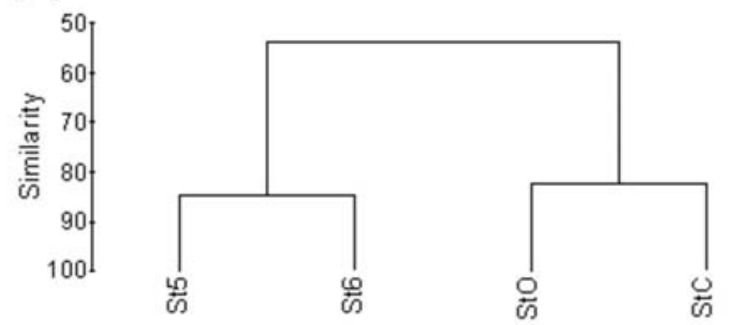

b) Abundance

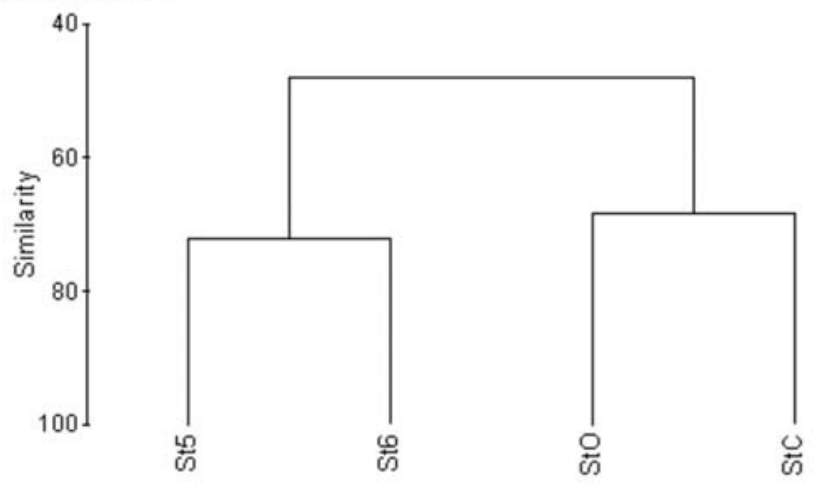


Figure 3
Click here to download high resolution image

Figure 3
Click here to download high resolution image
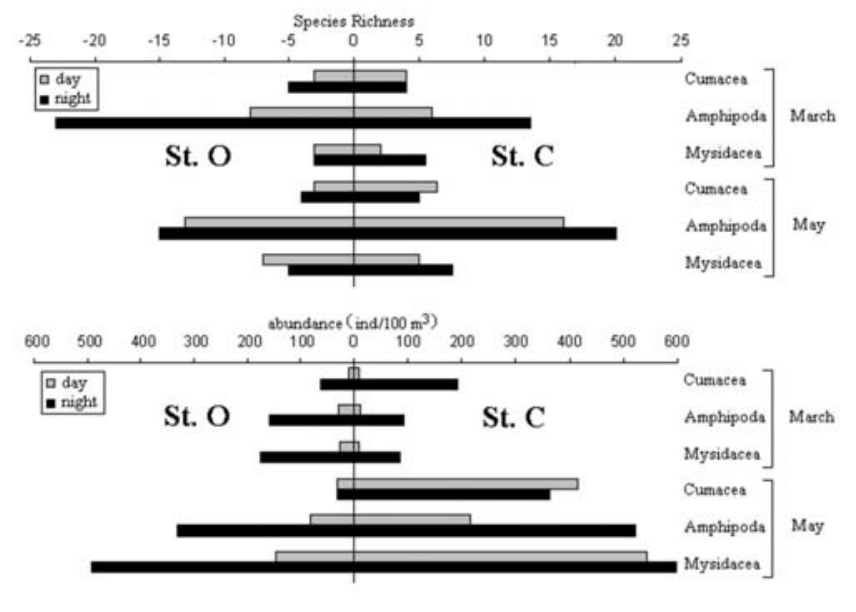
Figure 4
Click here to download high resolution image

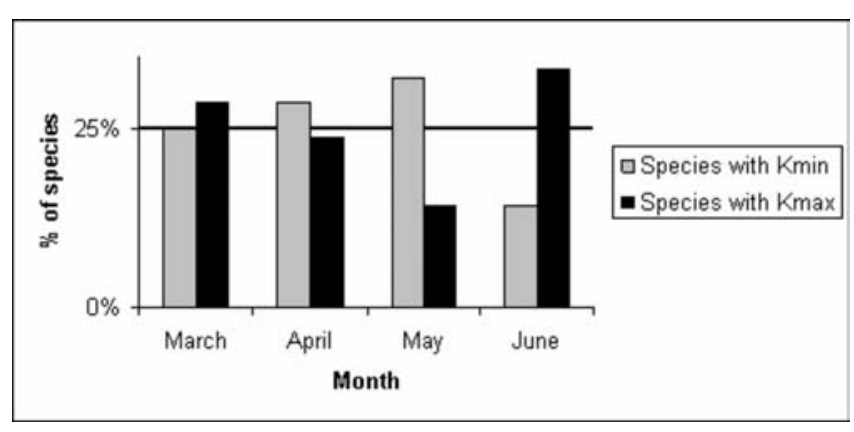




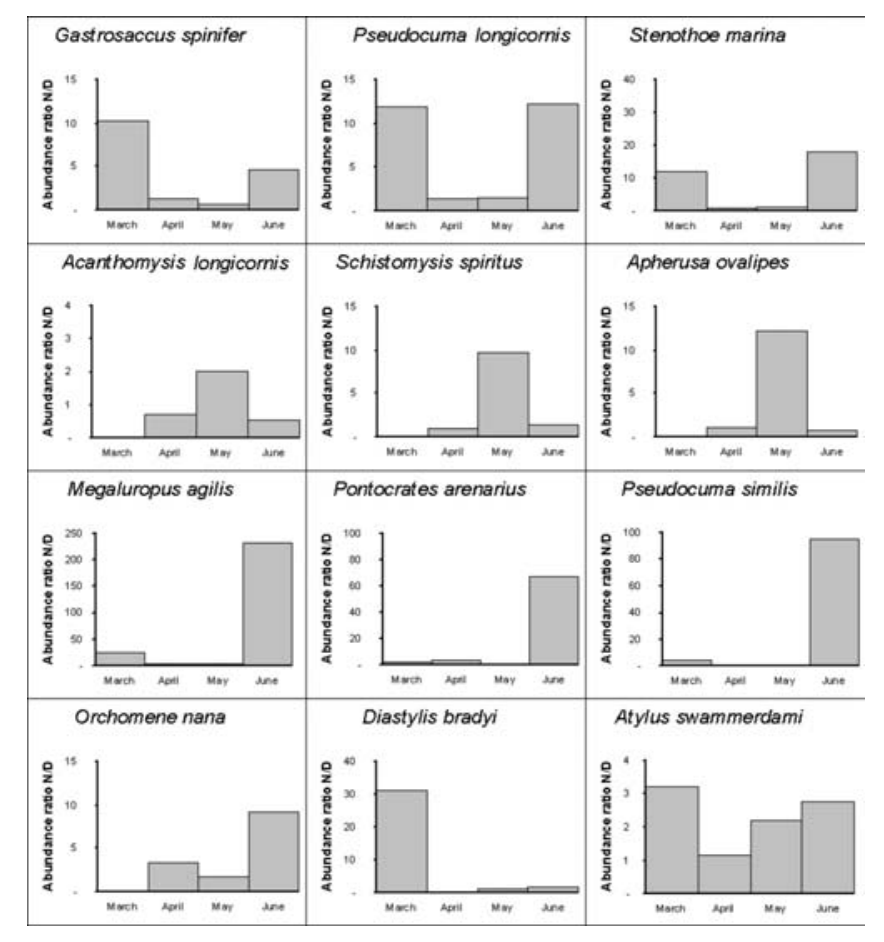

\section{Figure 5
Click here to download high resolution image}


Figure 6
Click here to download high resolution image

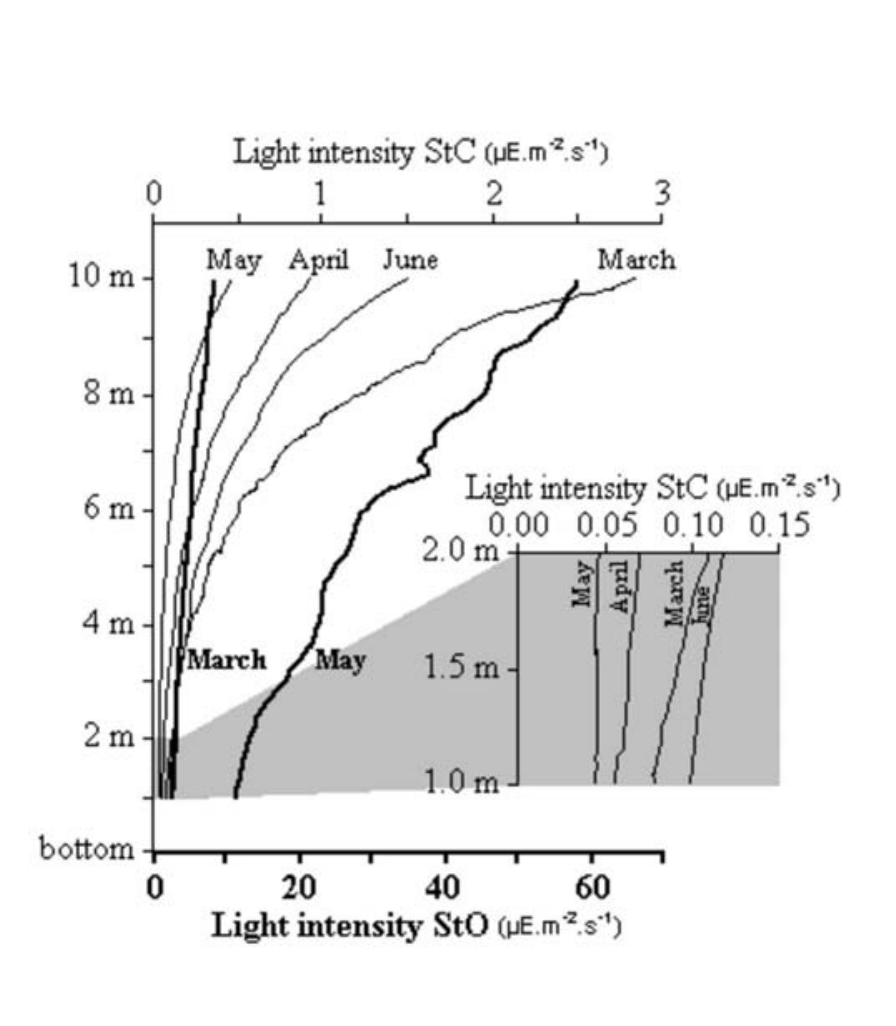

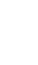

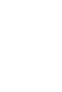

